\title{
Use of Principal Component Analysis to Investigate the Origin of Heptadecenoic and Conjugated Linoleic Acids in Milk
}

\author{
V. Fievez, ${ }^{\star}$ B. Vlaeminck, ${ }^{*}$ M. S. Dhanoa, $\dagger$ and R. J. Dewhurst $\dagger$ \\ *Department of Animal Production, Ghent University, \\ Proefhoevestraat 10, 9090 Melle, Belgium \\ †Institute of Grassland and Environmental Research, \\ Plas Gogerddan, Aberystwyth SY23 3EB, U.K.
}

\begin{abstract}
The aim of this paper was the application of principal component analysis (PCA) 1) to elucidate mutual metabolic relationships between milk fatty acids (FA) and 2) to illustrate the origin of milk FA, in particular $\mathrm{C}_{17: 1}$ and cis-9,trans-11 conjugated linoleic acid. Data were combined from 3 experiments with lactating HolsteinFriesian cows offered diets based on grass or legume silage and concentrates. Loading plots of PCA based on milk FA concentrations showed 4 groups of milk FA, having similar precursors or metabolic pathways in the rumen and/or mammary gland: medium-chain saturated FA, de novo synthesized from acetate and $\beta$-hydroxybutyrate; monoenoic milk FA, products of $\Delta^{9}$-desaturase activity in the mammary gland; odd chain FA of rumen microbial origin and $\mathrm{C}_{18: 0}, \mathrm{n}-6 \mathrm{C}_{18: 2}$, and $\mathrm{n}-3$ $\mathrm{C}_{18: 3}$ of dietary origin or the result of rumen biohydrogenation. Loading plots of PCA based on both milk and duodenal FA concentrations as well as on milk FA yields and duodenal FA flows further illustrated the importance of postabsorptive synthesis of the milk medium chain saturated and monoenoic FA and the direct absorption from the blood stream of odd chain FA, $\mathrm{C}_{18: 0}$, n-6 $\mathrm{C}_{18: 2}$, and n-3 $\mathrm{C}_{18: 3}$. In all loading plots, milk oleic acid $\left(\mathrm{C}_{18: 1}\right)$ appeared intermediate between clusters of 18-carbon FA and monoenoic FA, illustrating its dual (dietary and endogenous production) origin. Milk $\mathrm{C}_{17: 1}$ was suggested to be a desaturation product of $\mathrm{C}_{17: 0}$, in common with other milk monoenoic FA. Finally, the PCA technique, based on milk FA patterns of one experiment, was applied to investigate factors determining cis-9,trans-11 conjugated linoleic acid concentrations in milk. Within the range of diets and cows studied here, we showed changes in cis-9,trans-11 conjugated linoleic acid to be mainly dependent on vaccenic acid supply and to a lesser extent on variation in desaturase activity.
\end{abstract}

Received May 2, 2003.

Accepted August 12, 2003.

Corresponding author: V. Fievez; e-mail: veerle.fievez@UGent.be.
(Key words: principal component analysis; odd-chain fatty acid; conjugated linoleic acid; $\Delta^{9}$-desaturase)

Abbreviation key: FA = fatty acids, OCFA = oddchain fatty acids, PCA = principal component analysis .

\section{INTRODUCTION}

Milk odd-chain fatty acids (OCFA) (pentadecanoic acid, $\mathrm{C}_{15: 0}$; iso methyltetradecanoic acid, iso $\mathrm{C}_{15: 0}$; anteiso methyltetradecanoic acid, anteiso $\mathrm{C}_{15: 0}$; heptadecanoic acid, $\mathrm{C}_{17: 0}$; iso methylhexadecanoic acid, iso $\mathrm{C} 17: 0$; anteiso methylhexadecanoic acid, anteiso $\mathrm{C}_{17: 0}$; and heptadecenoic acid, $\mathrm{C}_{17: 1}$ ) were suggested to originate principally from rumen microbes (Dewhurst et al., 2000). However, only trace amounts of $\mathrm{C}_{17: 1}$ were detected in pure rumen bacteria (Miyagawa, 1982; Minato et al., 1988). This raises the possibility of other sources of $\mathrm{C}_{17: 1}$ in milk. Because $\Delta^{9}$-desaturase activity in the ruminant mammary tissue is responsible for the conversion of $\mathrm{C}_{14: 0}, \mathrm{C}_{16: 0}$, and $\mathrm{C}_{18: 0}$ into $\mathrm{C}_{14: 1}, \mathrm{C}_{16: 1}$, and $\mathrm{C}_{18: 1}$ (oleic acid), respectively (Bickerstaffe and Annison, 1970), we hypothesised that $\mathrm{C}_{17: 1}$ could be produced endogenously from $\mathrm{C}_{17: 0}$ in the mammary gland.

Principal component analysis (PCA) is often used to reduce the dimensionality of data profiles containing intercorrelated variables. Moreover, PCA aims to display the maximum amount of variation in a data profile within a few principal components. Hence, pairwise score plots derived from PCA are useful to find similarities and contrasts between samples, whereas correlations among variables can be identified in loading plots. The latter were used earlier to highlight similarity in metabolic pathways (Massart-Leën and Massart, 1981). Consequently, the aim of this study was to test our hypothesis of endogenous production of $\mathrm{C}_{17: 1}$ using PCA. A further objective was to apply this tool to investigate the importance of mammary $\Delta^{9}$-desaturase activity in the production of milk conjugated linoleic acid (cis9,trans- $11 \mathrm{C}_{18: 2}$ ). Indeed, postabsorptive synthesis from vaccenic acid (trans-11 $\mathrm{C}_{18: 1}$ ) has been suggested as the predominant source of milk cis-9,trans-11 $\mathrm{C}_{18: 2}$ (Griinari et al., 2000). This suggestion has led to increased 
interest in stimulating mammary $\Delta^{9}$-desaturase activity, particularly as a potential means to enhance cis9,trans- $11 \mathrm{C}_{18: 2}$ concentrations of dairy products (e.g., Lock and Garnsworthy, 2000).

\section{MATERIALS AND METHODS}

\section{Experimental Design and Diets}

The current study combined data from 3 experiments. All experiments were conducted according to a 4-period incomplete or complete changeover design. Each experimental period lasted for $28 \mathrm{~d}$. All diets were based on grass or legume silage and concentrate and offered to 4 or 6 lactating Holstein-Friesian cows with duodenal and rumen cannulas.

Experiment 1. Experimental design and diets are as described by Dewhurst et al. (2003a, 2003b). Briefly, the experiment was according to a 4-period incomplete changeover design, in which 6 cows in the beginning of the lactation were used to test 6 dietary treatments. Each cow was offered 4 different diets. Cows received $8 \mathrm{~kg} / \mathrm{d}$ of a standard dairy concentrate, in 3 portions: 3 $\mathrm{kg}$ at milking ( 0730 and $1600 \mathrm{~h}$ ) and $2 \mathrm{~kg}$ at $1200 \mathrm{~h}$. Concentrates contained $52 \mathrm{~g}$ of fatty acids (FA) per kilogram of DM, with $\mathrm{C}_{14: 0}, \mathrm{C}_{16: 0}, \mathrm{C}_{18: 0}, \mathrm{C}_{18: 1}, \mathrm{n}-6 \mathrm{C}_{18: 2}$, and $n-3 \mathrm{C}_{18: 3}$ being the most abundant $\mathrm{FA}$, representing $4.2,15.7,3.1,25.0,29.9$, and $2.0 \%$ of total FA, respectively. Cows had ad libitum access to one of the 6 silages: grass, red clover, white clover, alfalfa, and 50/50 (DM basis) mixtures of grass and red clover and grass and white clover. Each forage treatment comprised a proportional mixture of all cuts taken in the year. Fresh forage was distributed daily at $0900 \mathrm{~h}$. The FA levels in the different silages were similar (16 g/kg DM), although slightly higher for white clover silage $(22 \mathrm{~g} / \mathrm{kg}$ $\mathrm{DM}$ ). $\mathrm{C}_{16: 0}$ (19.3 to $\left.25.2 \%\right), \mathrm{C}_{18: 2}$ (16.0 to $23.1 \%$ ), and $\mathrm{C}_{18: 3}$ (41.0 to $55.0 \%$ ) represented over $90 \%$ of the FA (Dewhurst et al., 2003b). Average daily silage DMI was $10.2,13.9,12.1,14.9,13.6$, and $12.4 \mathrm{~kg}$ for the grass, grass-red clover, red clover, grass-white clover, white clover, and alfalfa silage based diet, respectively (Dewhurst et al., 2003b).

Experiment 2. This experiment was a $4 \times 4$ Latin square. Four dairy cows in midlactation were offered diets varying in forage-to-concentrate ratio. Dietary treatments were based on ad libitum access to ryegrass silage and a standard dairy concentrate with forage/ concentrate ratios of $80 / 20,65 / 35,50 / 50,35 / 65$ on a DM basis (Dewhurst et al., 2002; Moorby et al., 2002). Concentrates and grass silage contained 43 and $12 \mathrm{~g}$ of FA per kilogram DM, respectively. Predominant FA (\% of total $\mathrm{FA}$ ) in concentrates were $\mathrm{C}_{12: 0}(4.8 \%), \mathrm{C}_{16: 0}$ (16.9\%), $\mathrm{C}_{18: 1}(26.6 \%)$, n-6 $\mathrm{C}_{18: 2}(35.4 \%)$, and $\mathrm{n}-3 \mathrm{C}_{18: 3}$ (5.3\%), whereas grass silage FA mainly consisted of
$\mathrm{C}_{16: 0}(22.5 \%)$, n-6 $\mathrm{C}_{18: 2}(17.8 \%)$, and $\mathrm{n}-3 \mathrm{C}_{18: 3}(44.8 \%)$. Average daily DMI were $13.2,15.5,18.4$, and $20.7 \mathrm{~kg}$ for diets with forage to concentrate ratios of $80 / 20,65 /$ 35, 50/50, 35/65, respectively (Moorby et al., 2002).

Experiment 3. The experiment was designed as a 4 $\times 4$ Latin square experiment (Hindle et al., 2003). Cows in early lactation were offered grass silage/beet pulp/ concentrate in ratios of $43 / 27 / 30$ on a DM basis. Diets were distributed once daily as a TMR. All diets were isoenergetic and isonitrogenous and based on the animals' requirements for energy and protein. The four concentrates differed in amount of (protected) starch. Diets contained between 71 and $121 \mathrm{~g}$ of FA/kg DM with $\mathrm{C}_{12: 0}$ (2.2 to $\left.4.9 \%\right), \mathrm{C}_{14: 0}$ (1.2 to $\left.2.3 \%\right), \mathrm{C}_{16: 0}$ (14.4 to $15.8 \%), \mathrm{C}_{18: 0}(1.9$ to $3.0 \%), \mathrm{C}_{18: 1}$ (4.3 to $\left.10.0 \%\right)$, n$6 \mathrm{C}_{18: 2}$ (15.8 to $\left.28.2 \%\right)$ and $\mathrm{n}-3 \mathrm{C}_{18: 3}(29.6$ to $51.9 \%)$ representing over $90 \%$ of total FA. Average daily DMI was relatively constant and ranged from 18.1 to $19.6 \mathrm{~kg}$.

\section{Sampling}

In all three experiments, feed, duodenal, and milk samples, taken during the final week of each experimental period were used in the statistical analysis. In experiments 1 and 2, silage (composite of three) and concentrate samples were stored frozen and freezedried prior to chemical analysis. In experiment 3 , silage and concentrates were sampled together at feeding (TMR) and stored frozen. Daily samples were thawed and mixed prior to chemical analysis. Duodenal sampling in experiments 1 and 2 was performed over 2 consecutive days using the automated equipment described by Evans et al. (1981), 24-h duodenum samples were stored frozen and freeze dried prior to analysis. In experiment 3 , duodenal samples were collected every $4 \mathrm{~h}$ during 2 consecutive days and the 12 individual samples were mixed prior to freezing. Analysis was performed on freeze-dried samples. Milk samples were taken from 4 (experiments 1 and 2) or 8 (experiment 3) consecutive milkings, stored frozen without preservative and freeze-dried (experiments 1 and 2 ) or thawed (experiment 3) prior to FA analysis.

In experiment 1 , ytterbium acetate (mean $650 \mathrm{mg}$ of $\mathrm{Yb} / \mathrm{d}$ ) was infused into the rumen continuously as a marker to allow estimation of flows at the duodenum (Dewhurst et al., 2003a). Duodenal flows in experiments 2 and 3 were determined based on the double marker technique as described by Faichney (1992). In all 3 experiments, milk yields were recorded throughout the experiment, and mean values from the final week of each period were used for calculations of milk FA yields.

\section{Fatty Acid Analysis}

Feed, duodenal, and milk samples were used for extraction and methylation of FA and GLC analysis of 
FA methyl esters. In experiments 1 and 2, extraction and methylation of FA were based on the methods described by Sukhija and Palmquist (1988). Fatty acid methyl esters in feed and milk samples were analyzed by GLC using an Innowax column $(30 \mathrm{~m} \times 0.32 \mathrm{~mm}$ i.d.) (Phenomonex, Macclesfield, UK). For duodenal digesta of experiment 1 , a CP-Sil88 column $(50 \mathrm{~m} \times 0.25$ $\mathrm{mm}$ i.d.) (Chrompack, The Netherlands) was used, whereas FA methyl esters in duodenal samples of experiment 2 were separated by a chemically bonded CPSelect for FAME $(100 \mathrm{~m} \times 0.25 \mathrm{~mm}$ i.d. $)$ (Varian, Walton-on-Thames, UK). Extraction of milk FA in experiment 3 was according to the method of the International Organization for Standardization (ISO-3889). Extraction of feed and duodenal FA, methylation and GLC analysis of FA methyl esters were as described by Raes et al. (2001). Compared to the latter, the GLC temperature program was modified for milk FA analysis $\left(70^{\circ} \mathrm{C}\right.$ for $4 \mathrm{~min}, 13^{\circ} \mathrm{C} / \mathrm{min}$ until $175^{\circ} \mathrm{C}, 175^{\circ} \mathrm{C}$ for $27 \mathrm{~min}, 4^{\circ} \mathrm{C} /$ min until $215^{\circ} \mathrm{C}, 215^{\circ} \mathrm{C}$ for $31 \mathrm{~min}$ ). Thirteen FA were identified in common in all three experiments and both in duodenal and milk samples, i.e., $\mathrm{C}_{14: 0}, \mathrm{C}_{14: 1}$, iso $\mathrm{C}_{15: 0}$, $\mathrm{C}_{15: 0}, \mathrm{C}_{16: 0}, \mathrm{C}_{16: 1}$, iso $\mathrm{C}_{17: 0}, \mathrm{C}_{17: 0}, \mathrm{C}_{17: 1}, \mathrm{C}_{18: 0}, \mathrm{C}_{18: 1}, \mathrm{n}-6$ $\mathrm{C}_{18: 2}$, and n-3 $\mathrm{C}_{18: 3}$. As anteiso $\mathrm{C}_{15: 0}$ seemed to coelute with an unidentified FA on a $30 \mathrm{~m}$ column (experiments 1 and 2), this OCFA was excluded from the analysis. Anteiso $\mathrm{C}_{17: 0}$ was not considered either, as its concentrations in duodenal samples of experiment 1 seemed inexplicably high. For each of the 13 individual FA, means were calculated per cow and diet from 2 (duodenal samples of experiments 1 and 2), 4 (milk samples of experiments 1 and 2) or 8 (milk samples of experiment 3) FA analyses. Overall, we had duodenal and milk FA patterns from 56 experimental units $\left(\mathrm{x}_{\mathrm{ij}}\right.$, with $\mathrm{i}=1,13$; $\mathrm{j}=1,56)$. Unless otherwise stated, individual milk and duodenal FA were expressed as a proportion of total FA ( $\%$ of total FA), the latter being the sum of the 13 commonly determined FA.

\section{Statistics}

Fatty acid proportions (\% of total FA) in duodenal digesta and milk were compared using the general linear model (GLM) procedures (univariate) according to: $\mathrm{Y}_{\mathrm{ijk}}=\mu+\mathrm{A}_{\mathrm{i}}+\mathrm{B}_{\mathrm{j}}+\mathrm{C}_{\mathrm{k}}+\mathrm{AB}_{\mathrm{ij}}+\mathrm{AC}_{\mathrm{ik}}+\mathrm{BC}_{\mathrm{jk}}+\varepsilon_{\mathrm{ijk}}$, with $\mathrm{Y}_{\mathrm{ijk}}=\mathrm{FA}$ proportions; $\mathrm{A}_{\mathrm{i}}=$ diet effect; $\mathrm{B}_{\mathrm{j}}=$ animal effect; $\mathrm{C}_{\mathrm{k}}=$ sample origin (i.e., duodenal digesta or milk); $\mathrm{AB}_{\mathrm{ij}}$, $\mathrm{AC}_{\mathrm{ik}}, \mathrm{BC}_{\mathrm{jk}}=$ interactions between different factors; $\varepsilon_{\mathrm{ijk}}$ $=$ residual error.

Relationships between milk FA were evaluated from the loading plots of PCA, based on the correlation matrix (consisting of 13 variables), using SPSS (SPSS software for Windows, release 11.0, SPSS Inc.). Levels (\% of total FA) of the 13 milk FA from the 3 experiments

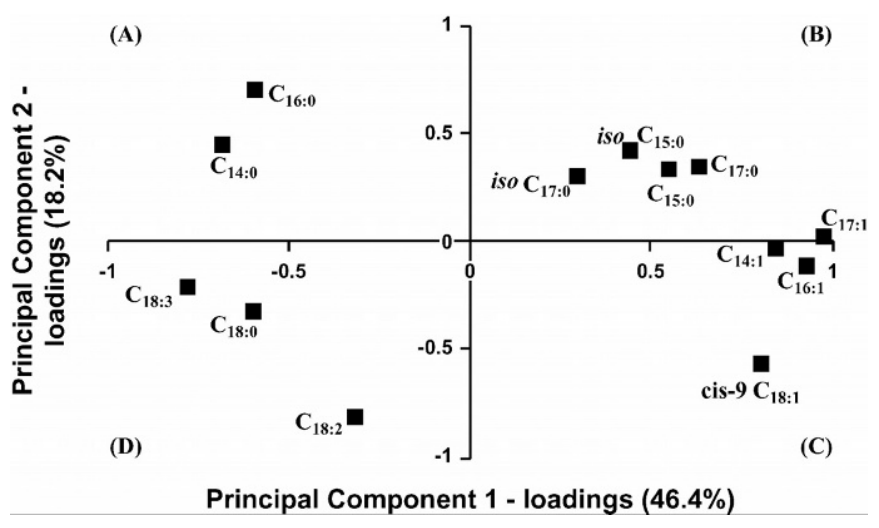

Figure 1. Loading plot, describing the relationships among milk fatty acids derived from a principal component analysis based on proportions (percentage of total fatty acids) of C14 to C18 fatty acids in milk from 3 experiments $(n=56)$.

were used in the latter PCA. Similarly, loading plots, based on FA concentrations (\% of total FA) as well as duodenal flows or milk yields ( $\mathrm{g} / \mathrm{d}$ ) of FA, were used to illustrate the origin of milk FA. Duodenal concentrations of $\mathrm{C}_{14: 1}$ and $\mathrm{C}_{17: 1}$ were below the detection limit in duodenal samples of experiments 1 and 2. Hence, including these duodenal FA in PCA may result in a (physiologically meaningless) contrast between samples of experiments 1 and 2 on the one hand and experiment 3 on the other. Hence, these duodenal FA were excluded from the latter PCA. Accordingly, the correlation matrix consisted of 24 variables (13 milk FA and 11 duodenal FA). Because trans- $11 \mathrm{C}_{18: 1}$ and cis-9,trans$11 \mathrm{C}_{18: 2}$ were not determined in milk from experiments 1 and 2, only data from experiment 3 could be used to investigate the importance of mammary $\Delta^{9}$-desaturase activity in the production of milk cis-9,trans- $11 \mathrm{C}_{18: 2}$. For this PCA, FA concentrations were expressed relative to 17 identified milk $\mathrm{FA}\left(\mathrm{C}_{14: 0}, \mathrm{C}_{14: 1}\right.$, iso $\mathrm{C}_{15: 0}$, anteiso $\mathrm{C}_{15: 0}, \mathrm{C}_{15: 0}, \mathrm{C}_{16: 0}, \mathrm{C}_{16: 1}$, iso $\mathrm{C}_{17: 0}$, anteiso $\mathrm{C}_{17: 0}, \mathrm{C}_{17: 0}, \mathrm{C}_{17: 1}$, $\mathrm{C}_{18: 0}, \mathrm{C}_{18: 1}, \mathrm{n}-6 \mathrm{C}_{18: 2}, \mathrm{n}-3 \mathrm{C}_{18: 3}$, trans- $11 \mathrm{C}_{18: 1}$, and cis9,trans-11 $\mathrm{C}_{18: 2}$ ). Grouping of FA in pairwise loading plots was evaluated based on squared Euclidean distances. Fatty acids with squared distances below 0.100 were considered to belong to the same group.

\section{RESULTS AND DISCUSSION}

The first (PC 1) and second (PC 2) principal components described $64.6 \%$ of the total variation in milk FA patterns of samples from the 3 experiments (Figure 1). In this loading plot, 4 groups of milk FA could be distinguished: $\mathrm{C}_{14: 0}$ and $\mathrm{C}_{16: 0}$ in quadrant (A); iso $\mathrm{C}_{15: 0}$, iso $\mathrm{C}_{17: 0}, \mathrm{C}_{15: 0}$ and $\mathrm{C}_{17: 0}$ in quadrant (B); $\mathrm{C}_{18: 0}, \mathrm{n}-3 \mathrm{C}_{18: 3}$, and $\mathrm{n}-6 \mathrm{C}_{18: 2}$ in quadrant (D); and $\mathrm{C}_{14: 1}, \mathrm{C}_{16: 1}$, and $\mathrm{C}_{17: 1}$ between quadrant (B) and (C). It is likely that FA form- 
ing a cluster follow a common metabolic pathway (Massart-Leën and Massart, 1981). $\mathrm{C}_{14: 0}$ and $\mathrm{C}_{16: 0}$, showing negative loadings for PC 1 and positive loadings for PC 2 are (partially) de novo-synthesized from acetate and $\beta$-hydroxybutyrate. These FA were separated by PC 2 from the 18-carbon FA, absorbed directly from the blood stream, and of dietary origin or the result of rumen biohydrogenation. The 4 milk OCFA showed positive loadings for both PC 1 and PC 2. Monoenoic milk FA, which are predominantly produced by $\Delta^{9}$-desaturase activity, had high positive loadings for PC 1 but were not correlated with PC $2 . \mathrm{C}_{18: 1}$ is close to this cluster, although showing a negative loading for PC 2, which might be due to the dual origin of milk $\mathrm{C}_{18: 1}$, i.e., directly absorbed from the circulatory system as well as endogenous production. Clustering of $\mathrm{C}_{17: 1}$ with $\mathrm{C}_{14: 1}$ and $\mathrm{C}_{16: 1}$ supports our hypothesis of endogenous production from $\mathrm{C}_{17: 0}$. In summary, 2 clusters were mainly determined by dietary factors or processes in the rumen, i.e., biohydrogenation of dietary FA and de novo synthesis of OCFA by rumen microbes. The 2 other groups were related to metabolic processes in the mammary gland. The importance of postabsorptive synthesis of $\mathrm{C}_{14: 0}$, $\mathrm{C}_{14: 1}, \mathrm{C}_{16: 0}, \mathrm{C}_{16: 1}, \mathrm{C}_{17: 1}$, and $\mathrm{C}_{18: 1}$ is further confirmed by their significantly higher proportions in milk than in duodenal samples (Table 1$)(P<0.001)$ and illustrated in the loading plot based on PCA of both milk and duodenal FA (Figure 2). Indeed, clustering of duodenal and milk n- $6 \mathrm{C}_{18: 2}$ and $\mathrm{n}-3 \mathrm{C}_{18: 3}$ on the one hand and milk and duodenal OCFA on the other hand illustrates the positive correlation between duodenal and milk levels of these FA. This could be expected as these FA are absorbed directly from the blood stream and do not undergo further transformation in the udder. Neither $\mathrm{C}_{14: 0}$ and $\mathrm{C}_{16: 0}$ nor monoenoic acids in milk clustered with duodenal $\mathrm{C}_{14: 0}$ and $\mathrm{C}_{16: 0}$ or monoenoic acids respectively. This illustrates milk levels of these FA are mainly determined by de novo synthesis in the udder and not by their duodenal supply. The negative loading for PC 1 of 18-carbon FA on the one hand and the positive loading of OCFA and monoenoic FA in milk on the other hand demonstrates that these FA are negatively correlated. Indeed, increased dietary fat supply (mainly 18-carbon $\mathrm{FA}$ and $\mathrm{C}_{16: 0}$ ) reduces the proportion of OCFA in duodenal contents and milk as de novo synthesis of odd chain FA by rumen bacteria remains constant or is partially inhibited at higher dietary fat levels (Demeyer et al., 1978). The negative correlation between 18-carbon FA and monoenoic milk FA could be the result of a partial inhibition of the $\Delta^{9}$-desaturase activity through increased concentrations of n-3 $\mathrm{C}_{18: 3}$ and $\mathrm{n}-6 \mathrm{C}_{18: 2}$ (Bickerstaffe and Annison, 1970). A similar picture emerged when running the statistical analysis with duodenal FA flows and milk FA yields, with

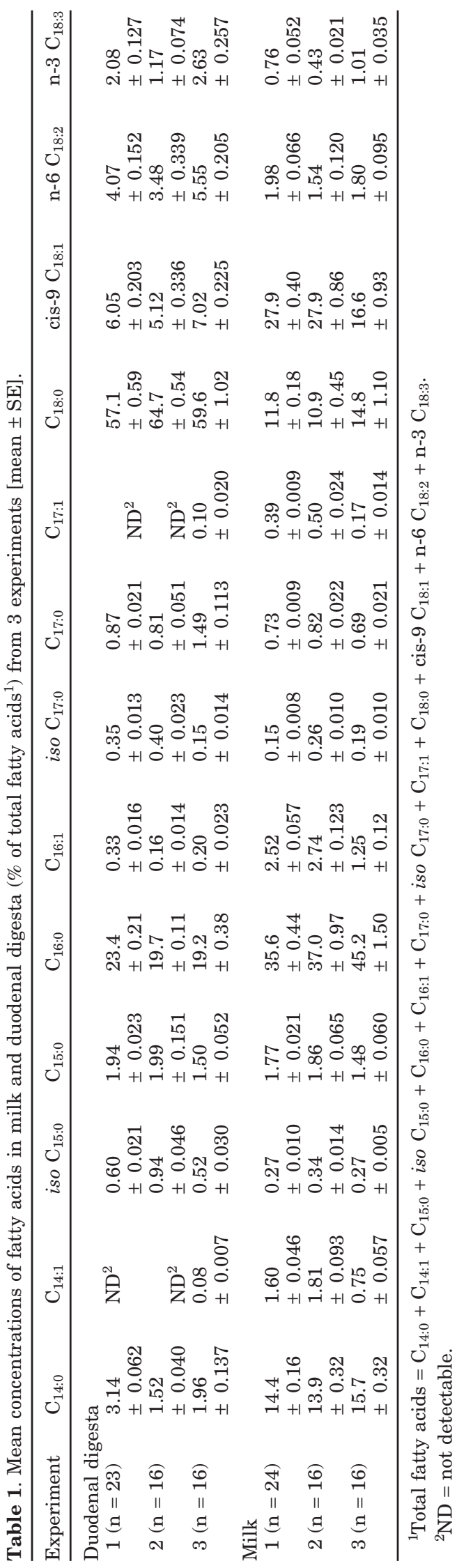




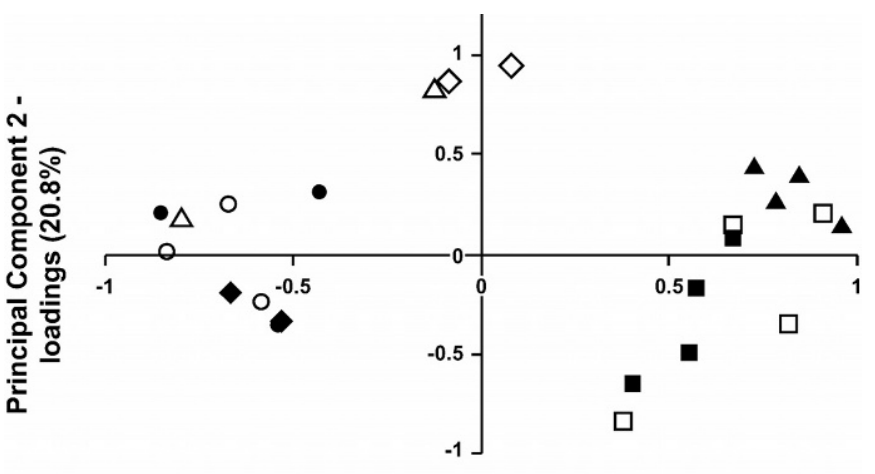

Principal Component 1 - loadings (42.5\%)

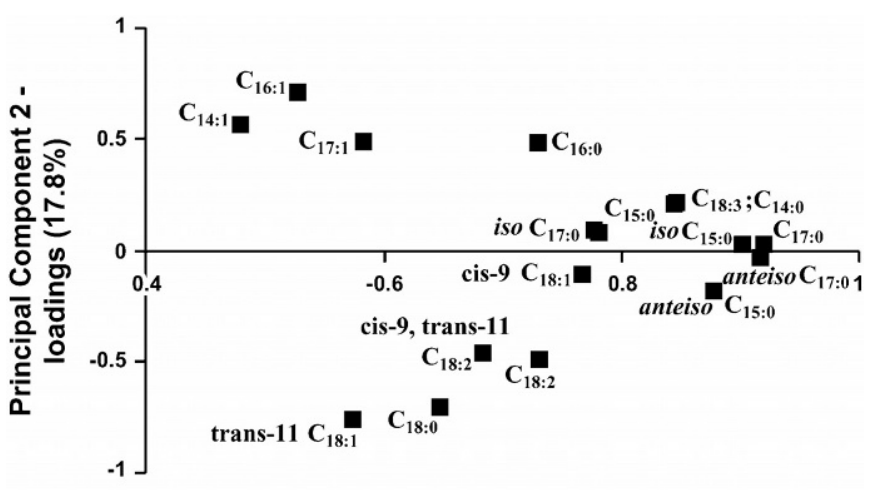

Principal Component 1 - loadings (56.6\%)

Figure 3. Loading plot, describing the relationships among milk fatty acids derived from a principal component analysis based on concentrations (\% of total fatty acids) of $\mathrm{C} 14$ to $\mathrm{C} 18$ fatty acids (including vaccenic acid, trans- $11 \mathrm{C}_{18: 1}$ and conjugated linoleic acid, cis9,trans-11 $\left.\mathrm{C}_{18: 2}\right)$ in milk from experiment $3(\mathrm{n}=122)$.

readily available long chain FA are supplied. Nevertheless, absolute duodenal flows of OCFA are mainly determined by outflow of rumen microbes. In the three experiments currently considered, milk yield, dietary fat intake as well as intake of rumen fermentable OM were highest in experiment 3 , resulting in increased flow and yields of both 18-carbon FA as well as microbial OCFA.

Interest in mammary $\Delta^{9}$-desaturase is growing as cis-9,trans-11 $\mathrm{C}_{18: 2}$ in milk was shown to be predominantly of endogenous origin (e.g., Griinari et al., 2000; Lock and Garnsworthy, 2002; Piperova et al., 2002). Low cis-9,trans- $11 \mathrm{C}_{18: 2}$ concentrations in duodenal digesta compared to milk (Table 2 ) and the close correlation between duodenal trans-11 $\mathrm{C}_{18: 1}$ and milk cis9 ,trans $-11 \mathrm{C}_{18: 2}\left(\mathrm{r}_{\text {pearson }}=0.876, P<0.001, \mathrm{n}=16\right)$ confirm the importance of endogenous cis-9,trans- $11 \mathrm{C}_{18: 2}$ production in the mammary gland. Clusters in the loading plot based on milk FA concentrations observed in experiment 3 (Figure 3) were not as obvious as when combining the 3 experiments (Figure 1), probably due to lower dietary variation. Nevertheless, clustering of $\mathrm{C}_{17: 1}$ with $\mathrm{C}_{14: 1}$ and $\mathrm{C}_{16: 1}$ reconfirms the importance of

Table 2. Mean ( $\pm \mathrm{SE}$ ), minimum and maximum concentrations of vaccenic acid (trans-11 $\left.\mathrm{C}_{18: 1}\right)$ and cis9 ,trans-11 conjugated linoleic acid (cis-9, trans-11 $\left.\mathrm{C}_{18: 2}\right)$ in duodenal digesta $(\mathrm{n}=15)$ and milk $(\mathrm{n}=16)(\%$ of total fatty acids ${ }^{1}$ ) and ratio $\mathrm{C}_{14: 1} / \mathrm{C}_{14: 0}$ in milk (g/g) of cows in experiment 3 .

\begin{tabular}{lllllll}
\hline & \multicolumn{2}{c}{ Duodenal digesta } & & \multicolumn{3}{c}{ Milk } \\
\cline { 2 - 3 } \cline { 5 - 7 } & trans-11 $\mathrm{C}_{18: 1}$ & cis-9, trans-11 $\mathrm{C}_{18: 2}$ & & trans-11 $\mathrm{C}_{18: 1}$ & cis-9, trans-11 $\mathrm{C}_{18: 2}$ & $\mathrm{C}_{14: 1} / \mathrm{C}_{14: 0}$ \\
\hline Mean & $3.18 \pm 0.201$ & $0.036 \pm 0.008$ & & $1.25 \pm 0.116$ & $0.32 \pm 0.013$ & $0.048 \pm 0.001$ \\
Min & 1.94 & $\mathrm{ND}^{2}$ & 0.11 & 2.36 & 0.14 & 0.020 \\
Max & 4.46 & 0.14 & 0.51 & 0.080 \\
\hline
\end{tabular}

${ }^{1}$ Total fatty acids $=\mathrm{C}_{14: 0}+\mathrm{C}_{14: 1}+$ iso $\mathrm{C}_{15: 0}+$ anteiso $\mathrm{C}_{15: 0}+\mathrm{C}_{15: 0}+\mathrm{C}_{16: 0}+\mathrm{C}_{16: 1}+$ iso $\mathrm{C}_{17: 0}+$ anteiso $\mathrm{C}_{17: 0}+$ $\mathrm{C}_{17: 0}+\mathrm{C}_{17: 1}+\mathrm{C}_{18: 0}+\mathrm{C}_{18: 1}+\mathrm{n}-6 \mathrm{C}_{18: 2}+\mathrm{n}-3 \mathrm{C}_{18: 3}+$ trans-11 $\mathrm{C}_{18: 1}+$ cis-9, trans- $11 \mathrm{C}_{18: 2}$.

${ }^{2} \mathrm{ND}=$ not detectable. 
$\Delta^{9}$-desaturase activity in the mammary gland for the production of $\mathrm{C}_{17: 1}$ (Figure 3). Despite the fact that up to $75 \%$ of cis-9,trans- $11 \mathrm{C}_{18: 2}$ was reported to be produced endogenously (Griinari et al., 2000; Lock and Garnsworthy, 2002; Piperova et al., 2002), it did not cluster with $\mathrm{C}_{14: 1}, \mathrm{C}_{16: 1}$ and $\mathrm{C}_{17: 1}$. On the contrary, cis-9,trans$11 \mathrm{C}_{18: 2}$ was located close to its precursor, trans- $11 \mathrm{C}_{18: 1}$ and a very strong correlation was observed between these 2 milk FA $\left(\mathrm{r}_{\text {pearson }}=0.808, P<0.001, \mathrm{n}=122\right)$. Close linear relationships between milk fat trans-11 $\mathrm{C}_{18: 1}$ and cis-9,trans-11 $\mathrm{C}_{18: 2}$ has been observed across a wide range of diets (e.g., review by Bauman et al., 1999), which was also visualized in a PCA loading plot previously (Jiang et al., 1996). Correlations between milk monoenoic FA and their precursors were far less strong $\left(\mathrm{C}_{14: 0}\right.$ vs. $\mathrm{C}_{14: 1}, \mathrm{r}_{\text {pearson }}=0.197, P=0.030 ; \mathrm{C}_{16: 0}$ vs. $\mathrm{C}_{16: 1}, \mathrm{r}_{\text {pearson }}=0.433, P<0.001 ; \mathrm{C}_{17: 0}$ vs. $\mathrm{C}_{17: 1}, \mathrm{r}_{\text {pearson }}$ $=0.355, P<0.001 ; \mathrm{C}_{18: 0}$ vs. cis-9 $\mathrm{C}_{18: 1}, \mathrm{r}_{\text {pearson }}=0.383$, $P<0.001, \mathrm{n}=122$ ). Apparently, within the range of cows and diets studied in experiment 3 , differences in milk cis-9,trans-11 $\mathrm{C}_{18: 2}$ were determined mainly by variation in the duodenal supply of trans- $11 \mathrm{C}_{18: 1}$ rather than by variation in $\Delta^{9}$-desaturase activity. The latter is further confirmed by the absence of any correlation between milk cis-9,trans- $11 \mathrm{C}_{18: 2}$ and $\mathrm{C}_{14: 1} / \mathrm{C}_{14: 0}\left(\mathrm{r}_{\text {pearson }}\right.$ $=-0.127, P=0.165, \mathrm{n}=122$ ), which has been identified as a good indicator of $\Delta^{9}$-desaturase activity (Lock and Garnsworthy, 2002). Correlations between $\mathrm{C}_{14: 1} / \mathrm{C}_{14: 0}$ and monoenoeic acid concentrations $\left(\mathrm{C}_{14: 1}, \mathrm{C}_{16: 1}, \mathrm{C}_{17: 1}\right.$, and $\left.\mathrm{C}_{18: 1}\right)$ were dramatically higher $\left(\mathrm{r}_{\text {pearson }}=0.958\right.$, $0.522,0.769$, and 0.541 , respectively; $P<0.001 ; \mathrm{n}=122$ ). Solomon et al. (2000) proposed substantial differences among individual cows in milk cis-9,trans- $11 \mathrm{C}_{18: 2}$ could be due to: 1) differences in the production of trans-11 $\mathrm{C}_{18: 1}$ in the rumen, 2) differences in the rumen accumulation of cis-9,trans-11 $\mathrm{C}_{18: 2}$, or 3) differences between individual cows in tissue activity of $\Delta^{9}$-desaturase. Individual cows in the current experiment showed considerable differences in $\Delta^{9}$-desaturase activity, as suggested by $\mathrm{C}_{14: 1} / \mathrm{C}_{14: 0}$ ratios across treatments varying between 0.032 and 0.062 . However, both the separation of cis9,trans- $11 \mathrm{C}_{18: 2}$ from $\mathrm{C}_{14: 1}, \mathrm{C}_{16: 1}$, and $\mathrm{C}_{17: 1}$ in the loading plot and its strong correlation with duodenal and milk trans- $11 \mathrm{C}_{18: 1}$ suggest that the conversion of cis-9,trans$11 \mathrm{C}_{18: 2}$ was mainly precursor driven, rather than dependent on variation in desaturase activity. Nevertheless, differences in tissue activity of $\Delta^{9}$-desaturase might play a secondary role, as suggested from the significant partial correlation between milk cis-9,trans$11 \mathrm{C}_{18: 2}$ and $\mathrm{C}_{14: 1} / \mathrm{C}_{14: 0}$ when controlling for milk trans$11 \mathrm{C}_{18: 1}$ concentration $\left(\mathrm{r}_{\text {partial }}=0.533, P<0.001, \mathrm{n}=122\right)$.

\section{CONCLUSIONS}

Loading plots of PCA appear to offer an interesting approach to indicate mutual metabolic relationships between milk FA and to illustrate origin of milk FA. Using this tool, $\mathrm{C}_{17: 1}$ was identified to be a desaturation product of its saturated precursor, $\mathrm{C}_{17: 0}$, in common with other milk monoenoic FA. Moreover, this study revealed milk cis-9,trans- $11 \mathrm{C}_{18: 2}$ concentrations to be mainly dependent on the trans-11 $\mathrm{C}_{18: 1}$ supply, rather than determined by the $\Delta^{9}$-desaturase activity, at least within the range of diets and cows studied here.

\section{ACKNOWLEDGMENTS}

The stay of Veerle Fievez at the Institute of Grassland and Environmental Research (Aberystwyth, UK) was supported by a postdoctoral fellowship of the Fund for Scientific Research-Flanders and of the Faculty of Agricultural and Applied Biological Sciences-Ghent University. Ph.D. research of Bruno Vlaeminck is supported by the Flemish Institute for the Promotion of Scientific-Technological Research. The financial support (experiments 1 and 2) of the Milk Development Council and the Department for Environment, Food and Rural Affairs (UK) is gratefully acknowledged. The authors are very grateful for the cooperation of A. van Vuuren and his team (Nutrition and Food, Animal Sciences Group, Wageningen, UR, The Netherlands) within experiment 3.

\section{REFERENCES}

Bauman, D. E., L. H. Baumgard, B. A. Corl, and J. M. Griinari. 1999. Biosynthesis of conjugated linoleic acid in ruminants. Proc. Am. Soc. Anim. Sci. Available: http://www.asas.org/jas/symposia/proceedings/0937.pdf. Accessed Jan. 29, 2003.

Bickerstaffe, R., and E. F. Annison. 1970. The desaturase activity of goat and sow mammary tissue. Comp. Biochem. Physiol. 35:653-665.

Demeyer, D., C. Henderson, and R. A. Prins. 1978. Relative significance of exogenous and de novo synthesized fatty acids in the formation of rumen microbial lipids in vitro. Appl. Environ. Microbiol. 35:24-31.

Dewhurst, R. J., R. T. Evans, N. D. Scollan, J. M. Moorby, R. J. Merry, and R. J. Wilkins. 2003a. Comparison of grass and legume silages for milk production. 2 . In vivo and in sacco evaluations of rumen function. J. Dairy Sci. 86:2612-2621.

Dewhurst, R. J., W. J. Fisher, J. K. S. Tweed, and R. J. Wilkins. 2003b. Comparison of grass and legume silages for milk production. 1. Production responses with different levels of concentrate. J. Dairy Sci., 86:2598-2611.

Dewhurst, R. J., J. M. Moorby, J. Danelón, and J. K. S. Tweed. 2002. Effect of diet forage:concentrate ratio on odd-chain fatty acids in milk from Holstein-Friesian cows. J. Dairy Sci. 85(Suppl. 1):318. (Abstr.)

Dewhurst, R. J., J. K. S. Tweed, and G. B. Williams. 2000. Variation in the concentrations of odd-chain fatty acids in milk. Page 29 in Proc. 25th Conf. Rumen Funct., Chicago, IL.

Evans, R. T., K. V. Skelton, and D. E. Beever. 1981. Portable equipment for the automatic sampling of duodenal contents from housed or grazing cattle. Lab. Pract. 30:997-1000.

Faichney, G. J. 1992. Effect of non-uniform distribution of particleassociated markers on the measurement of duodenal digesta flow by the double-marker technique. J. Agric. Sci. 118:119-120.

Griinari, J. M., B. A. Corl, S. H. Lacy, P. Y. Chouinard, K. V. V. Nurmela, and D. E. Bauman. 2000. Conjuated linoleic acid is 
synthesized endogenously in lactating diary cows by delta-9-desaturase. J. Nutr. 130:2285-2291.

Hindle, V. A., A. M. van Vuuren, A. Klop, and J. W. Cone. 2003. An evaluation of in vitro estimates for the amounts of rumen bypass starch and whole tract starch digestibility in dairy cattle. J. Dairy Sci. (accepted).

Jiang, J., L. Bjoerck, R. Fondén, and M. Emanuelson. 1996. Occurence of conjugated cis-9,trans-11-octadecadienoic acid in bovine milk: effects of feed and dietary regimen. J. Dairy Sci. 79:438-445.

Lock, A. L., and P. C. Garnsworthy. 2002. Independent effects of dietary linoleic and linolenic fatty acids on the conjugated linoleic acid content of cows' milk. Anim. Sci. 74:163-176.

Massart-Leën, A. M., and D. L. Massart. 1981. The use of clustering techniques in the elucidation or confirmation of metabolic pathways. Biochem. J. 196:611-618.

Minato, H., S. Ishibashi, and T. Hamaoka. 1988. Cellular fatty acid and sugar composition of representative strains of rumen bacteria. J. Gen. Appl. Microbiol. 34:303-319.

Miyagawa, E. 1982. Cellular fatty acid and fatty aldehyde composition of rumen bacteria. J. Gen. Appl. Microbiol. 28:389-408.
Moorby, J. M., R. J. Dewhurst, J. Danelón, R. T. Evans, and M. A. Neville. 2002. Effect of diet forage:concentrate ratio on digesta flow and milk production in mid-lactation Holstein-Friesian cows. J. Dairy Sci. 85(Suppl. 1):318. (Abstr.)

Piperova, L. S., J. Sampugna, B. B. Teter, K. F. Klascheur, M. P. Yurawecz, Y. Ku, K. M. Morehouse, and R. A. Erdman. 2002. Duodenal and milk trans octadecenoic acid and conjugated linoleic acid (CLA) isomers indicate that postabsorptive synthesis is the predominant source of cis-9-containing CLA in lactating dairy cows. J. Nutr. 132:1235-1241.

Raes, K., S. De Smet, and D. Demeyer. 2001. Effect of double-muscling in Belgian Blue young bulls on the intra muscular fatty acid composition with emphasis on conjugated linoleic acid and polyunsaturated fatty acids. Anim. Sci. 73:253-260.

Solomon, R., L. E. Chase, D. Ben-Ghedalia, and D. E. Bauman. 2000 The effect of nonstructural carbohydrate and addition of full fat extruded soybeans on the concentration of conjugated linoleic acid in the milk fat of dairy cows. J. Dairy Sci. 83:1322-1329.

Sukhija, P. S., and D. L. Palmquist. 1988. Rapid method for the determination of total fatty acid content and composition of feedingstuffs and feces. J. Agric. Food Chem. 36:1202-1206. 